\title{
SIDUMO REVISITED - AN ARTICLE ON THE DEVELOPMENT OF THE REVIEW TEST IN SOUTH AFRICA
}

\author{
MJ Boyens \\ LLB LLM \\ Provincial Manager of Employers Organisation and \\ Labour Law Attorney
}

Adriaan van der Walt

BJuris $B A$ (Hons) LLB

Associate Professor of Law, Nelson Mandela

Metropolitan University, Port Elizabeth

\section{SUMMARY}

The primary purpose of the second article in a series of two, is to revisit and reconsider the development of the review test set out in the Constitutional Court judgment of Sidumo v Rustenburg Platinum Mines Ltd ((2007) 28 ILJ 2405 (CC)), and consequently ascertain the correct approach to be adopted by our Labour Courts in the application of such test. The secondary purpose entails the determination of the extent to which Labour Court judges interfere with the merits of awards and the resulting impact on the distinction between appeal and review. In order to establish whether the test for review was correctly developed and to determine whether our review proceedings deter recurrent interference by our judges, a consideration of judicial review in South Africa, an extensive analysis of various judgments pertaining to such development, and a comprehensive comparison with the United Kingdom's application of review proceedings are made. The Sidumo contour is unpacked firstly. This discussion is followed by an evaluation of three contentious Labour Appeal Court judgments and concluding with a Supreme Court of Appeal judgment, which clarifies the operation of the review test. The contour is interlinked with the notion of reasonableness.

The judgment in Herholdt v Nedbank Ltd (2013) 34 ILJ 2795 (SCA), concluding the Sidumo contour, underlines the current position in our law and consequent narrower approach. A comparison made with the United Kingdom, differentiates between such approach implemented by our courts and the strict gross unreasonableness approach applied by Employment Appeal Tribunals, recognising the finding, that South African Labour Court judges ardently interfere with the merits of awards. In the conclusion it is submitted that our labour law jurisprudence will constantly evolve, dictated by the interpretation of lawfulness, reasonableness and fairness in South African jurisprudence. 


\section{THE LAC JUDGMENTS - THE TRILOGY}

\section{Introduction}

The majority in the Constitutional Court judgments of Sidumo established a stringent test for review, curtailing to a certain extent the interference by Labour Court judges in the awards of commissioners. It would be expected that subsequent judgments would continue in the pursuit of the further development of the so-called Sidumo test. However, the jurisprudence that followed the Sidumo judgment was contentious, since the fundamental starting point of each of the Labour Appeal Court judgments, was the minority judgment in Sidumo, Ngcobo's gross-irregularity dictum. Besides the endorsement of such minority view, one judgment in particular, went as far as to conclude that an award can be set aside, without establishing the Sidumo test. Consequently, this departure from the Sidumo contour and broader view, resulted in the further relaxation of the distinction between appeals and reviews.

In considering these judgments, we shall set out the focal dictum of each and analyse such pronouncement in relation to the development of the Sidumo test. In order to appreciate the nature of the terms referred to by the various judgments, and to avoid unnecessary reiteration, a useful summation by Myburgh, ${ }^{1}$ setting out a range of meanings and descriptions, is relied upon.

\section{Gaga v Anglo Platinum Ltd ${ }^{3}$}

The LAC was tasked to establish whether there was a rational basis justifying the commissioner's conclusion that there was no sexual harassment committed by the group human resources manager in regard to his personal assistant. ${ }^{4}$ The said employee appealed to the LAC, after the employer had successfully reviewed the commissioner's award. The LAC thus had to ascertain whether the commissioner had ignored the material facts and considerations and subsequently failed to apply his mind accurately to such material evidence. ${ }^{5}$ Murphy AJA held as follows:

1 Myburgh "The Test for Review of CCMA Arbitration Awards: An Update" 201323 Contemporary Labour Law 31-32.

2 Myburgh 201323 Contemporary Labour Law 31-32: "Section 145 or the grounds listed in s 145: the reviewable defects of misconduct, gross irregularity and excess of powers listed in s 145(2) of the LRA, 'Latent irregularity': an irregularity which occurs in the mind of a commissioner at the time of writing his or her award and appears from it - for example, material facts were ignored. It equates to an act of dialectical unreasonableness. 'Patent irregularity': an irregularity which occurs during the course of the arbitration proceedings and which constitutes a breach of the rules of procedural fairness. 'Substantive unreasonableness': an unreasonable result. 'Dialectical unreasonableness': an unreasonable process failure (in the cognitive sense) involving, for example, the failure by a commissioner to consider material facts. 'Process-related review': a review application based on an attack on a commissioner's reasoning and findings of fact, which typically highlights the failure to consider material facts and errors of fact."

(2012) 33 ILJ 329 (LAC).

The CCMA award was set aside on review by the Labour Court.

Gaga v Anglo Platinum Ltd supra par 43. 
"Where a commissioner fails properly to apply his mind to material facts and unduly narrows the inquiry by incorrectly construing the scope of an applicable rule, he will not fully and fairly determine the case before him. The ensuing decision inevitably will be tainted by dialectical unreasonableness (processrelated unreasonableness), characteristically resulting in a lack of rational connection between the decision and the evidence and most likely an unreasonable outcome (substantive unreasonableness). There will often be an overlap between the ground of review based on a failure to take into consideration a relevant factor and one based on the unreasonableness of a decision. If a commissioner does not take into account a factor that he is bound to take into account, his or her decision invariably will be unreasonable. The flaw in process alone will usually be sufficient to set aside the award on the grounds of it being a latent gross irregularity, permitting a review in terms of section $145(1)$ read with section $145(2)(a)$ (ii) of the LRA."

This dictum in Gaga, is based on the pronouncement of $\mathrm{Ngcobo} \mathrm{J}$, in Sidumo. It emphasises the principle that the failure by the commissioner to apply his or her mind to the material facts, prevents the party from having his or her matter determined on a fair basis and thus constitutes a latent irregularity, justifying the setting-aside of an award. ${ }^{7}$ Such approach in Gaga is accordingly confirmed by the citation of Ngcobo's gross-irregularity dictum, ${ }^{8}$ in support of the LAC's finding. Murphy AJA, however, continued and expounded the two forms of unreasonableness, ${ }^{9}$ by referring to dialectical unreasonableness, which constitutes an unreasonable-process failure, occurring in the mind of the commissioner and substantive unreasonableness comprising of an unreasonable result. ${ }^{10}$ The judge contended that an unreasonable-process failure, for example, the failure by a commissioner to consider the material facts, will recurrently amount in an unreasonable result. This Court accordingly concluded that dialectical unreasonableness and substantive unreasonableness will often overlap, however, the unreasonable-process failure itself will be sufficient to sustain a review. $^{11}$

As a result, the LAC held that the commissioner's irregularity in excluding similar-fact evidence in this matter was sufficient to uphold the review, ${ }^{12}$ in that such absence of similar-fact evidence has a bearing on the

\footnotetext{
Gaga v Anglo Platinum Ltd supra par 44.
}

7 Myburgh "The LAC's Latest Trilogy of Review Judgments: Is the Sidumo Test in Decline?" 201334 ILJ 121.

8 Murphy AJA, in Gaga v Anglo Platinum Ltd supra par 44; set out that, in the minority judgment in Sidumo Ngcobo J, (as he then was) in effect distinguished review on grounds of dialectical unreasonableness from substantive unreasonableness, when he observed: "It follows therefore that where a commissioner fails to have regard to material facts, the arbitration proceedings cannot in principle be said to be fair because the commissioner fails to perform his or her mandate. In so doing the commissioner's action prevents the aggrieved party from having its case fully and fairly determined. This constitutes a gross irregularity in the conduct of the arbitration, as contemplated in section 145(2)(a)(ii) of the LRA. And the ensuing award falls to be set aside not because the result is wrong but because the commissioner has committed a gross irregularity in the conduct of the arbitration proceedings."

9 Southern Sun Hotel Interests (Pty) Ltd v CCMA [2009] 11 BLLR 1129 (LC) par 14-17.

10 Myburgh 201323 Contemporary Labour Law 32.

11 Myburgh 201334 ILJ 20.

12 Gaga v Anglo Platinum Ltd supra par 46. 
determination of an appropriate sanction in this case ${ }^{13}$ and a failure to have regard to same, hamper a full and fair determination of the issues. ${ }^{14}$

\section{Afrox Healthcare Ltd $v$ Commission for Conciliation, Mediation \& Arbitration ${ }^{15}$}

The issue to be determined by the LAC, was whether the reasonableness of the commissioner's award, in which it was found that the appellant had led no evidence to substantiate the charges brought against the employee, based on alleged negligence, in that the employee had failed to supervise untrained nursing staff, resulting in the death of a patient. This failure to present such evidence consequently resulted in the conclusion by the commissioner that there was no negligence on the part of the employee. ${ }^{16}$ Mlambo JP, held as follows:

"The fact of the matter is that the reasonable decision maker yardstick crafted in Sidumo, viewed in proper context, is none other than that in the absence of a 'rational objective basis' between the decision arrived at and the material placed before the decision maker, the relevant decision is clearly not one which a reasonable decision maker would have arrived at." ${ }^{17}$

The LAC in Afrox Healthcare accordingly found that the reasonable decision-maker yardstick as per Sidumo is equivalent to the absence of a "rational objective basis" between the decision arrived at and the material facts before such decision-maker; thus in essence relying on Ngcobo J's gross-irregularity dictum. ${ }^{18}$

In drawing on the above dictum, the LAC assessed the commissioner's reasoning in relation to the material placed before him and subsequently established such failure, where there was an absence of a rational and objective basis between them. ${ }^{19}$ In considering the consequences of such failure, the LAC in Afrox Healthcare accordingly centred its finding, firstly on the distinction between two types of reviews, the first of which where the commissioner had failed to consider all the material evidence and secondly, how the commissioner had treated such evidence in determining the award. ${ }^{20}$ The former is the challenge entertained in Afrox Healthcare, inter alia, a process-related review. ${ }^{21}$ On the pronouncement of the issues in dispute, Mlambo JP, clarified his view in relation to that of the commissioner, in respect of having a different analysis. He confirmed that the LAC is not responsible for determining the fairness of the dismissal. ${ }^{22}$ Thus, respecting

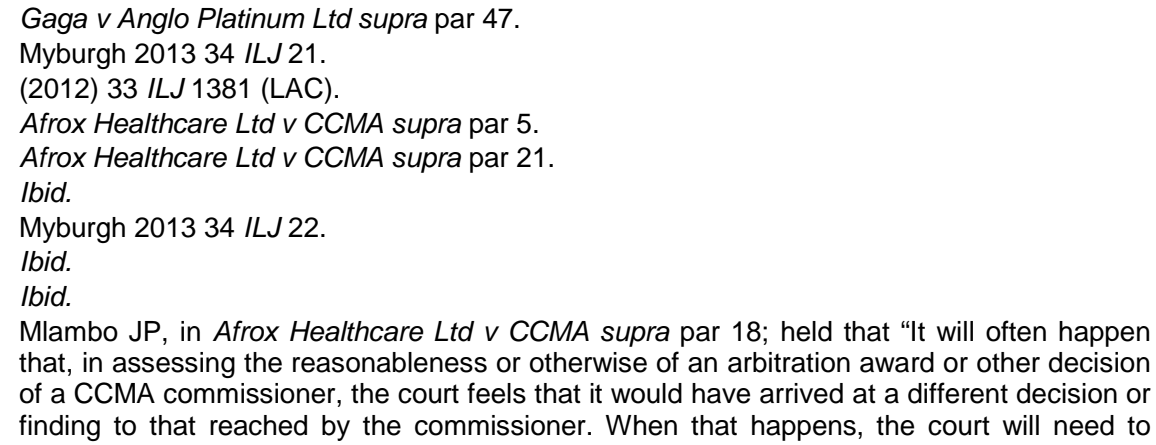
of a CCMA commissioner, the court feels that it would have arrived at a different decision or finding to that reached by the commissioner. When that happens, the court will need to 
the line between appeal and review. The LAC proceeded and thus argued that such view entertained by the said court, is based on the holistic analysis of the evidence, which the commissioner, in arriving at his decision, did not take into consideration. ${ }^{23}$ Thus, failing to consider the material placed before him, in particular certain critical considerations, ${ }^{24}$ led him to arrive at an unreasonable result. ${ }^{25}$

Mlambo JP relied on Ngcobo and the dictum ${ }^{26}$ in Minister of Health $v$ New Clicks South Africa (Pty) $L t d{ }^{27}$ in concluding that the commissioner failed the Sidumo test, by failing to apply his mind to the material evidence, which had a bearing on the ultimate conclusion, resulting in the award being unreasonable. $^{28}$

\section{Herholdt v Nedbank Ltd ${ }^{29}$}

Herholdt concerned a probe into whether the commissioner committed a reviewable defect, by ruling that the employee, a financial planner, did not act with dishonest intent, when he failed to disclose to his employer that he was a beneficiary in a dying client's will, as per Nedbank's conflict-of-interest policy. ${ }^{30}$ The appeal was refused by the LAC, upholding the judgment of the Labour Court, that the dismissal was substantively fair. Murphy AJA, pronounced:

"One of the duties of a commissioner is to determine the material facts and then to apply the provisions of the LRA to those facts in answering the question whether the dismissal was for a fair reason. Commissioners who do not do so do not fairly adjudicate the issues and the resulting decision and award will be unreasonable. Whether or not an arbitration award or decision or finding of a commissioner is reasonable must be determined objectively

remind itself that the task of determining the fairness or otherwise of such a dismissal is in terms of the Act primarily given to the commissioner and that the system would never work if the court would interfere with every decision or arbitration award of the CCMA simply because it, that is the court, would have dealt with the matter differently. Obviously, this does not, in any way, mean that decisions or arbitration awards of the CCMA are shielded from scrutiny of the Labour Court on review."

23. Afrox Healthcare Ltd v CCMA supra 16.

24 Ibid.

25 Mlambo JP, in Afrox Healthcare Ltd v CCMA supra 19: In considering the abovementioned lapse by the commissioner, Mlambo JP, referred to the judgment of National Union of Mine Workers $v$ Samancor Ltd, where the SCA overturned the judgment of the LAC, holding that the court a quo incorrectly approached the matter as an appeal and not review. The SCA in Samancor thus found that the LAC failed the application of the Sidumo test, in that the material before the commissioner cast no doubt that his decision was not so unreasonable that it could not have been reached by a reasonable decision-maker.

26 Minister of Health $v$ New Clicks South Africa (Pty) Ltd 2006 (1) BCLR 1 (CC) par 511: "There is obviously an overlap between the ground of review based on failure to take into consideration a relevant factor and one based on the unreasonableness of the decision. A consideration of the factors that a decision maker is bound to take into account is essential to a reasonable decision. If a decision maker fails to take into account a factor that he or she is bound to take into consideration, the resulting decision can hardly be said to be that of a reasonable decision maker."

27 Minister of Health v New Clicks South Africa (Pty) Ltd supra par 511.

28 Myburgh 201334 ILJ 23.

29 (2012) 23 ILJ 1789 (LAC).

30 Myburgh 201323 Contemporary Labour Law 32. 
with due regard to all the evidence that was before him or her and what the issues were. There is no requirement that the commissioner must have deprived the aggrieved party of a fair trial by misconceiving the whole nature of enquiry. The threshold for interference is lower than that, it being sufficient that the commissioner has failed to apply his mind to certain of the material facts or issues before him, with such having potential for prejudice and the possibility that the result may have been different. This standard recognises that dialectical and substantive reasonableness are intrinsically inter-linked and that latent process irregularities carry the inherent risk of causing an unreasonable substantive outcome."

In the analysis of the abovementioned dictum, several key conclusions can be drawn in respect of the test for review, the standard of review and impact of Sidumo. The dictum is based on the premise that one of the duties of a commissioner is to consider the material facts before him or her and then subsequently applying his or her mind in establishing the fairness of the dismissal.

Therefore, at the outset, a failure by a commissioner to consider the material facts, will result in the unfair adjudication of the dispute and the award thus being unreasonable. ${ }^{32}$ Such unreasonableness relates to the failure by the commissioner to determine the material facts, resulting in the unfairness of the award. ${ }^{33}$ Such failure could either constitute a gross irregularity as per Ngcobo J's gross irregularity dictum or dialectical unreasonableness, demonstrating an unreasonable-process failure, as a result of failure by commissioner to consider material facts. ${ }^{34}$ Therefore, such failure to consider the material facts, results in either a gross irregularity or an unreasonable-process failure, resulting in the award being unreasonable.

Secondly, Murphy AJA, expounded on such substantive unreasonableness of the award, ${ }^{35}$ and referred to as "Sidumo test", ${ }^{36}$ and held that the notion of reasonableness is determined objectively, in the consideration of all the evidence that was before the commissioner, and does not require that such failure by the commissioner amounts to the misconceiving of the whole nature of the enquiry. ${ }^{37}$ It is therefore sufficient that the commissioner had only to misconstrue certain of the material evidence before him, which has

31 Herholdt $v$ Nedbank Ltd supra par 39 - emphasised by Myburgh in Myburgh 201323 Contemporary Labour Law 32.

32 Herholdt $v$ Nedbank Ltd supra par 39.

33 Herholdt $v$ Nedbank Ltd supra par 32.

34 Myburgh 201323 Contemporary Labour Law 32; "Dialectical unreasonableness" was a term coined by the LAC based principally on the finding by the Constitutional Court in Minister of Health v New Clicks South Africa (Pty) Ltd (Treatment Action Campaign \& Another as amici curiae) 2006 (2) SA 311 (CC) par 511: "A consideration of the factors that a decision-maker is bound to take into account is essential to a reasonable decision. If a decision-maker fails to take into account a factor that he or she is bound to take into consideration, the resulting decision can hardly be said to be that of a reasonable decision-maker."

35 Myburgh 201323 Contemporary Labour Law 32; Substantive unreasonableness is encompassed in the test set in par 110 of the majority judgment of the Constitutional Court in Sidumo \& Another v Rustenburg Platinum Mines Ltd [2007] 12 BLLR 1097 (CC): "Is the decision reached by the commissioner one that a reasonable decision-maker could not reach?"

36 Ibid.

Herholdt $v$ Nedbank Ltd supra par 39. 
the potential for prejudice and possibility that the result may be different. ${ }^{38}$ Accordingly, based on the fact that dialectical unreasonableness bears the potential risk of causing an unreasonable-substantive outcome, the notion that both dialectical and substantive unreasonableness are interlinked. ${ }^{39}$

It is evident from the interpretation that Murphy AJA endorsed a lighter test for prejudice. In order to comprehend such undemanding test to succeed on review, Myburgh ${ }^{40}$ explains that one of three tests for prejudice theoretically stands to be satisfied where a commissioner failed to apply his/her mind to the material facts. Such tests for prejudice are set out on the hypothetical analysis of whether the result of the award:

(1) may have been different;

(2) would have been different; or

(3) is rendered unreasonable, ${ }^{41}$

if the commissioner had considered the facts ignored by him $/ \mathrm{her}^{42}$

Murphy AJA accentuated in his dictum that it was sufficient that the failure by the commissioner to apply his or her mind to only some of the material facts before him or her, resulting in the potential for prejudice and the possibility that the result may be different. It is therefore the lightest of the tests for prejudice set out above, and if such straightforward test is met, the award will be set aside on the grounds of either a gross irregularity or dialectical unreasonableness, without the result of the award being substantively unreasonable. ${ }^{43}$ An award can accordingly be set aside on process-related grounds, without establishing the Sidumo test. ${ }^{44}$

In reaching such conclusion, the Labour Appeal Court subsequently endorsed the view of the court a quo, and held that the commissioner committed a gross irregularity by ignoring relevant evidence and failed to apply his or her mind to a number of material issues. ${ }^{45}$ The LAC refused the appeal. ${ }^{46}$

\section{Conclusion}

In summary, the judgments of Gaga, Afrox Healthcare and Herholdt neither endorsed nor developed the Sidumo test in a constructive manner. Instead, these Labour Appeal Court judgments endorsed and widened the approach by the labour courts in relation to the intervention in arbitration awards. The legal position established by the said judgments, confirmed that CCMA awards can be reviewed on section 145 grounds and, in addition on the

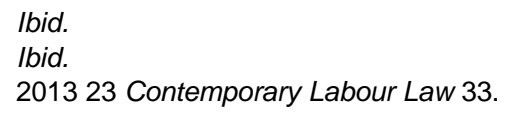


basis of unreasonableness. ${ }^{47}$ Furthermore, concerning the types of reviews, the judgments concluded that there are two different types, that being patent irregularities and latent irregularities. ${ }^{48}$ In addition, it was also established that substantive unreasonableness and dialectical unreasonableness equate to two different categories of unreasonableness. ${ }^{49}$ The former concerns the Sidumo test, based on the unreasonableness of the award, and the latter, where a commissioner fails to apply his mind to the material facts. ${ }^{50}$ Herholdt, in particular, ascertained that substantive unreasonableness and dialectical unreasonableness are interlinked, in that an unreasonableprocess failure will often lead to an unreasonable result. Pertaining to Ngcobo's gross-irregularity dictum, where a commissioner fails to apply his mind to the material facts, resulting in the unfair adjudication of the dispute and thus constitutes a latent irregularity, which accordingly equates to dialectical unreasonableness. ${ }^{5}$

The concern is the effortless interference in the review of such gross irregularity or dialectical unreasonableness, based on the potential-forprejudice-test. This intervention by the Labour Court is even more simplified, as a result of the interlinking of substantive unreasonableness and dialectical unreasonableness. Thus, based on this light test for review, a mere failure by the commissioner to consider the material facts, that might "potentially" cause an unreasonable-substantive outcome, causes the award to be set aside. Therefore, this interference of the line between appeals and reviews and the ensuing relaxation of such distinction result in there being even no need to show substantial unreasonableness, but a mere potential for prejudice as a result of the commissioner's failure to consider the material facts, or the unfair adjudicating of the hearing itself, which is sufficient to set aside the award. The direction followed by the Labour Appeal Court judgments and in particular Herholdt, makes it therefore easier to succeed on review than on appeal, ${ }^{52}$ which contradicts the objectives of the legislature, in that disputes under the LRA must be resolved expeditiously. ${ }^{53}$

This misapplication of the Sidumo test encouraged applicants on review to rather base their application on a gross irregularity or dialectical unreasonableness. ${ }^{54}$ This created a deviation from the Sidumo contour, resulting in the unjustifiable relaxation of the grounds of review, in divergence of the intention of the Legislature. Where Sidumo attempted to correct such unjustifiable inclination with a more stringent test, Gaga, Afrox Healthcare and Herholdt slacken such view endorsed by the Constitutional Court. It was thus up to the Supreme Court of Appeal ${ }^{55}$ and a subsequent Labour Appeal Court judgment to set the matter straight and recoup the more inflexible approach to be followed by Labour Court judges, and thus maintain the strict distinction between appeal and review.

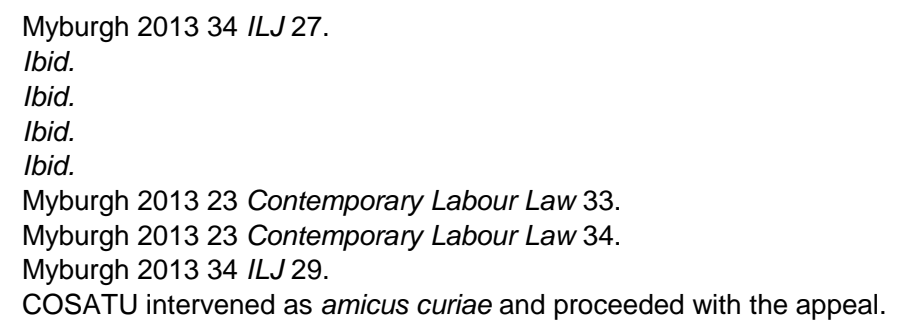




\section{THE LATER JUDGMENTS OF SCA AND LAC - THE RESPONSE}

\section{Introduction}

The SCA judgment in Herholdt $v$ Nedbank $L t d^{56}$ and subsequent LAC judgment in Gold Fields Mining SA (Pty) Ltd v CCMA ${ }^{57}$ sought to correct the broad approach established by the trilogy, ${ }^{58}$ in endorsing a more restricted approach, based on the true intention of the legislature. In essence, the judgments emphasised the true meaning ${ }^{59}$ set out in section 145 of the LRA concerning the review ground of gross irregularity, as well as the stringent nature of the Sidumo test, ensuring that awards are not lightly interfered with, and preserving the distinction between appeal and review.

The divergence from Sidumo purged the notion of reasonableness, resulting in the distortion of the proverbial fine line between appeals and reviews. It is thus evident that the notion of reasonableness holds the key in process-related reviews. Without the reliance on the sound conception of the Sidumo test, it is merely required that the arbitrator apply his mind to the material facts in establishing whether the dismissal was for a fair reason. Such simple application formed the basis for the LAC judgment in Herholdt. This misapplication of the Sidumo test encouraged applicants on review to rather base their application on a gross irregularity or dialectical unreasonableness. ${ }^{61}$

Hence, the SCA in Herholdt and LAC in Gold Fields endorsed the suffusion of the constitutional standard of reasonableness, albeit based on different approaches. Herholdt (SCA) established that awards can be reviewed both on the listed ground in section 145 and on the ground of unreasonableness. Gold Fields, to the contrary, held that awards are reviewable only on the section 145 listed grounds, if the additional requirement of unreasonableness has been met. ${ }^{6}$

This paragraph will commence of with an analysis of the SCA judgment of Herholdt, in considering the historical view of the meaning of a gross irregularity and in addition, the operation of the Sidumo test. The significant aspect of the analyses, concerns the rejection by the SCA of the inaccurate development of the review test by the court a quo. The analysis culminates in the consideration that the SCA narrowed the scope for interference by Labour Court judges and in the process preserved the distinction between appeal and review.

Gold Fields was the first judgment dealing with the review test that followed the SCA judgment. Even though Gold Fields endorsed the Sidumo test and was in line with the development established by the SCA in

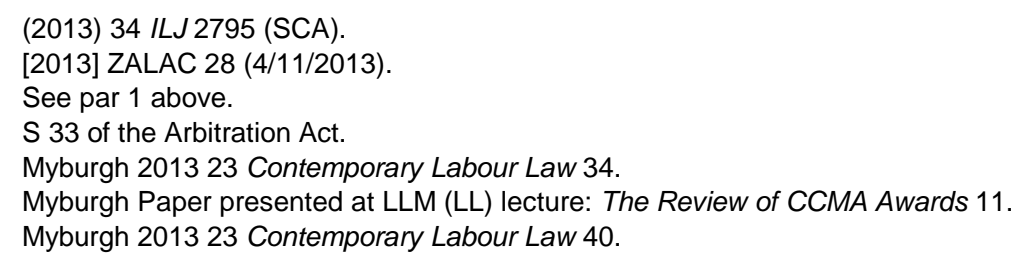


Herholdt, the judgment recognised an excessive approach, with a more burdensome requirement to succeed on review. In considering that both judgments endorsed the notion of unreasonableness, the approach of the SCA is to be preferred ${ }^{63}$ and it is therefore unnecessary to analyse the Gold Fields judgment in great detail. A brief comparison of the two judgments suffices.

\section{Herholdt $v$ Nedbank Ltd}

The development of the review test was at the core of this Supreme Court of Appeal judgment. The particular development in question concerned the court a quo's relaxation of the grounds to challenge CCMA awards on review, ${ }^{64}$ in that the LAC endorsed the lightest test for prejudice, ${ }^{65}$ and concluded that if such straightforward test is met, the award will be set aside on the grounds of either a gross irregularity or dialectical unreasonableness, without the need to establish the Sidumo test, consequently, encouraging applicants on review to rather base their application on a gross-irregularity or dialectical unreasonableness.

In the analysis of the inaccurate development of the review test by the LAC, the SCA in Herholdt sought to reaffirm the position in our law. Cachalia $\mathrm{JA}$, and Wallis JJA, in the process of scrutinising the LAC judgment, sought to underline and re-establish the importance and preservation of the distinction between appeal and review.

In concluding that the LAC had erred in its development of the review test, ${ }^{66}$ the SCA considered the historical view of the meaning of a gross irregularity and in addition, the operation of the Sidumo test. Such considerations set the basis for the conclusion and the subsequent rejection of the LAC's development of the review test. In reaching such conclusion, the SCA dealt with and subsequently analysed the formulation of the incorrect development by setting out the notions of latent irregularities and dialectical unreasonableness, which formed the basis of the Labour Appeal Court judgment.

\section{Gross irregularity}

The legislature, with the intention of formulating an informal and expeditious resolution of disputes arising from the Labour Relations Act, selected arbitration as the dispute-resolution mechanism and consequently mirrored section 145(2) on corresponding legislation ${ }^{67}$ in the Arbitration Act. ${ }^{68}$ The drafters of the LRA thus emphasised, through such limited grounds contained in section 145(2), the intention to deter parties in challenging

\footnotetext{
Myburgh 201323 Contemporary Labour Law 37.

Myburgh 201323 Contemporary Labour Law 34.

See paragraph 1 above.

Myburgh 201323 Contemporary Labour Law 31.

S 33.

42 of 1965.
} 
arbitration awards and impede upon the inexpensive and expeditious resolution of such disputes. ${ }^{69}$

One of such narrow grounds contemplated in section 145(2) and which is also reflected in the Arbitration Act, is that of a gross irregularity. This ground of review concerns the conduct of the proceedings, rather than the merits of the decision. ${ }^{70}$

The SCA was thus of the view that the legislature intended a gross irregularity, as reflected in section 145(2), to be based on the corresponding legislation contained in section 33 of the Arbitration Act, and consequently interpreted to relate to the conduct of the proceedings, where the commissioner misconceives the whole nature of the enquiry. This high standard for setting aside an award, is thus indicative of the historical intention of the legislature in preventing the effortless interference of arbitration awards.

A further advance in challenging an award on the ground of a gross irregularity, was developed in the Constitutional judgment of Sidumo $v$ Rustenburg Platinum Mines Ltd. ${ }^{72}$ This advance was significant, as it related to the suffusion of the constitutional standard of reasonableness. ${ }^{73}$ The SCA thus assessed and set out the legal position after Sidumo.

\section{The operation of the Sidumo test}

The SCA clarified the operation of the Sidumo test and subsequently concluded that the unreasonable test set out in Sidumo concerned the holistic examination by the reviewing court of all the merits, and consequently assessing whether the award was one that a reasonable decision-maker could not reach. ${ }^{74}$ The reasoning of the commissioner is to be considered, enabling the reviewing court to ascertain whether the result reached by such commissioner could have reasonably been reached by taking such route. Thus, Cachalia JA, and Wallis JJA, confirmed the operation of the Sidumo test and concluded that the legal position after Sidumo entailed as follows:

"Reviews could be brought on the unreasonableness test laid down by the Constitutional Court and the specific grounds set out in ss 145(2)(a) and (b) of the LRA. The latter had not been extinguished by the Constitutional Court but were to be 'suffused' with the constitutional standard of reasonableness. What this meant simply is that a 'gross irregularity in the conduct of the arbitration proceedings' as envisaged by s 145(2)(a)(ii) of the LRA, was not confined to a situation where the arbitrator misconceives the nature of the enquiry, but

Herholdt $v$ Nedbank Ltd supra par 9

70 Herholdt v Nedbank Ltd supra par 10 - it was held that a "gross irregularity" is committed where decision-makers misconceive the whole nature of the enquiry and as a result misconceive their mandate or their duties in conducting the enquiry.

71 Myburgh 201323 Contemporary Labour Law 34 - Myburgh refers to this as the "historical meaning".

2 [2007] 12 BLLR 1097 (CC).

73 Myburgh 201323 Contemporary Labour Law 34.

74 Herholdt $v$ Nedbank Ltd supra par 12. 
extended to those instances where the result was unreasonable in the sense explained in that case."

The SCA accordingly concluded that commissioners commit a gross irregularity if they misconceive the whole nature of the enquiry or if they produce an unreasonable award. ${ }^{76}$ The former is based on the historical meaning of a gross irregularity and the latter on the Sidumo test.

It might therefore be interpreted that this SCA judgment both narrowed and widened the test for gross irregularity. ${ }^{77}$ However, with reference to Sidumo, it was emphasised by the SCA, that even though the reviewing court exercises the assessment and scrutiny of the merits, ${ }^{78}$ the court should always be careful in avoiding "judicial overzealousness in setting aside administrative decisions that do not coincide with the judge's own opinions". ${ }^{79}$ Hence, the SCA referred to the judgment of Fidelity Cash Management Service $v \mathrm{CCMA}^{80}$ and held:

"The LAC subsequently stressed that the test is a stringent [one] that will ensure that ... awards are not lightly interfered with' and that its emphasis is on the result of the case rather than the reasons for arriving at that result. The Sidumo test will, however, justify setting aside an award on review if the decision is disconnected with the 'evidence' or is 'unsupported by any evidence' and involves speculation by the commissioner."

To summarise: the SCA endorsed the view that the Sidumo test will ensure that awards are not lightly interfered with, by only placing emphasis on the result of the case, thus assessing whether the award was one that a reasonable decision-maker could not reach. It is therefore evident that the approach endorsed by the SCA is to preserve the distinction between review and appeal, ${ }^{82}$ and not simply set aside an award if the reviewing court would have reached a different conclusion.

Sidumo established a sound advance in respect of the grounds of review $^{83}$ and thus established a clear position for such test for review. ${ }^{84}$ However, such progressive view, which preserved the distinction between appeal and review, was distorted by subsequent judgments, in particular the LAC judgment in Herholdt. Such judgments aimed at providing a more generous standard for the review of CCMA-arbitration awards. ${ }^{85}$ The SCA therefore sought to bring an end to such counter-development in considering and analysing the pivotal formulation set out by the LAC, under the heads of latent irregularity and dialectical unreasonableness.

\footnotetext{
Herholdt $v$ Nedbank Ltd supra par 14.

Myburgh 201323 Contemporary Labour Law 34.

Ibid.

See $R v$ Dhlumayo 1948 (2) SA 678 (A).

Herholdt $v$ Nedbank Ltd supra par 13.

(2008) 29 ILJ 964 (LAC)

Herholdt $v$ Nedbank Ltd supra par 13.

Ibid.

See Labour Relations Act 66 of 1995.

Herholdt v Nedbank Ltd supra par 14.

Herholdt v Nedbank Ltd supra par 15.
} 


\section{Latent irregularity}

The SCA defined a latent irregularity ${ }^{86}$ as the failure by the arbitrator to take into account a material fact in determining the arbitration. ${ }^{87}$ The court also described such irregularity to include the converse, where the commissioner took into account a totally irrelevant fact. ${ }^{88}$ Should the abovementioned irregularities occur, it is perceived as a latent irregularity and it subsequently justifies the setting aside of the award.

In considering the approach endorsed by the LAC, Cachalia JA, and Wallis JJA, analysed and considered the authority relied upon by the court a quo. The LAC in Herholdt relied upon an approach established in Southern Sun Hotel Interests (Pty) Ltd $v$ CCMA. ${ }^{89}$ The basis of this approach, according to the SCA, concerns dual considerations. Firstly, the threshold for interference with the award of the commissioner is lower than the interference established in Sidumo ${ }^{90}$ and secondly, it is irrelevant whether the result reached by the commissioner is one that could have been reasonably reached with the material before such commissioner. It was concluded by the SCA that the mere possibility of prejudice will suffice to warrant interference by the reviewing court. ${ }^{91}$ The premise of the abovementioned approach, is the dictum ${ }^{92}$ of the minority judgment of Ngcobo J, (as he then was) in Sidumo.

The SCA, in analysing the minority judgment, disregarded the dictum of Ngcobo $\mathrm{J}$, as such approach is contrary to that of the majority judgment in Sidumo, ${ }^{93}$ and that such approach can therefore not be accepted. ${ }^{94}$

\footnotetext{
Also referred to as a process-related unreasonableness. Herholdt $v$ Nedbank Ltd supra par 16.

Ibid.

89 Supra par 17 - The court held that "If a commissioner fails to take material evidence into account, or has regard to evidence that is irrelevant, or the commissioner commits some other misconduct or a gross irregularity during the proceedings under review, and a party is likely to be prejudiced as a consequence, the commissioner's decision is liable to be set aside regardless of the result of the proceedings or whether on the basis of the record of the proceedings, that result is nonetheless capable of justification."

92 "Fairness in the conduct of the proceedings requires a commissioner to apply his or her mind to the issues that are material to the determination of the dispute. One of the duties of a commissioner in conducting an arbitration is to determine the material facts and then to apply the provisions of the LRA to those facts in answering the question whether the dismissal was for a fair reason. In my judgment, where a commissioner fails to apply his or her mind to a matter which is material to the determination of the fairness of the sanction, it can hardly be said that there was a fair trial of issues."

93 Herholdt $v$ Nedbank Ltd supra par 19.

94 Herholdt $v$ Nedbank Ltd supra par 20 - the majority, in contrast, held that the arbitrator had erred in certain respects in making his award, in particular in holding that the relationship of trust between employer and employee had not been breached, but held that it was nonetheless an award that a reasonable decision-maker could make in the light of all the facts. In other words, the approach of the majority was clearly inconsistent with the approach suggested by Ngcobo J. As we, and all courts, are bound by the majority judgment the development of the notion of latent irregularity, in the sense that it has
} assumed in the labour courts, cannot be accepted. 
Despite the rejection of Ngcobo J's dictum, the SCA contended that a latent irregularity may well equate to a gross irregularity within the meaning of section 145(2)(a)(ii), but only in a narrower sense, "where the decisionmaker has undertaken the wrong enquiry or undertaken the enquiry in the wrong manner". ${ }^{95}$

The SCA thus substantially limited the approach endorsed by the LAC, ${ }^{96}$ in concluding that the court cannot merely rely on the failure by the commissioner to apply his mind to the material facts, to succeed on review. ${ }^{97}$ In order to succeed on review, the applicant has to establish that the result was unreasonable. ${ }^{98}$ In addition, the SCA reiterated that such limited application of a latent irregularity should be based on the historical meaning of a "gross irregularity" and subsequently read together with the Sidumo test, in the instance where the commissioner produces an award which fails the Sidumo test. ${ }^{99}$ Accordingly, the SCA adopted a considerably narrower approach than that of the LAC and rejected the basis for the approach set out by the court a quo.

The SCA in Herholdt, however, continued and scrutinised the inaccurate development of the review test by the LAC, by consequently considering the other formulation set out by the LAC in support of such development.

\section{Dialectical unreasonableness}

The SCA briefly considered the notion of dialectical unreasonableness, in defining it as an unreasonableness flowing from the process of reasoning adopted by the commissioner. The LAC based its interpretation on whether the arguments and thought process of the commissioner were reasonable. ${ }^{100}$ This approach adopted by the LAC, was based on Ngcobo J's dictum in the Constitutional Court judgment of New Clicks. ${ }^{101}$ However, the SCA found that the abovementioned dictum related to the provisions of PAJA and the manner in which they are to be applied ${ }^{102}$ and thus concluded:

"As PAJA does not apply to reviews under s 145(2) of the LRA it is of no application to CCMA awards. Second, if applied by considering the reasoning

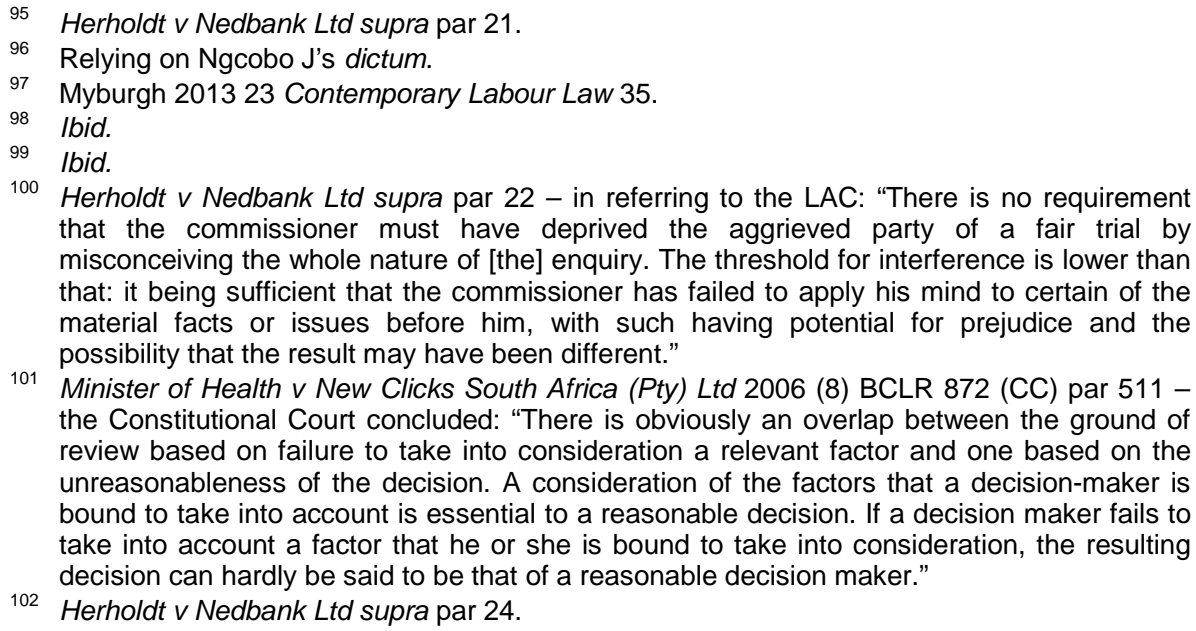
misconceiving the whole nature of [the] enquiry. The threshold for interference is lower than that: it being sufficient that the commissioner has failed to apply his mind to certain of the material facts or issues before him, with such having potential for prejudice and the possibility that the result may have been different."

101 Minister of Health v New Clicks South Africa (Pty) Ltd 2006 (8) BCLR 872 (CC) par 511 the Constitutional Court concluded: "There is obviously an overlap between the ground of review based on failure to take into consideration a relevant factor and one based on the unreasonableness of the decision. A consideration of the factors that a decision-maker is bound to take into account is essential to a reasonable decision. If a decision maker fails to take into account a factor that he or she is bound to take into consideration, the resulting decision can hardly be said to be that of a reasonable decision maker."

102 Herholdt $v$ Nedbank Ltd supra par 24. 
of a CCMA arbitrator and determining that the reasons given for making an award are not such as to justify that award, its effect is to resuscitate this court's decision in Rustenburg Platinum Mines Ltd (Rustenburg Section) v Commission for Conciliation, Mediation and Arbitration, supra, even though that decision was expressly overruled in Sidumo. Once again that is not a permissible development of the law."

Hence, the SCA held that the reliance on such passage from New Clicks, had no basis in law.

\section{Conclusion}

In concluding its finding, the SCA summarised the current legal position as follows:

"In summary, the position regarding the review of CCMA awards is this: A review of a CCMA award is permissible if the defect in the proceedings falls within one of the grounds in $s$ 145(2)(a) of the LRA. For a defect in the conduct of the proceedings to amount to a gross irregularity as contemplated by $s 145(2)(a)(i i)$, the arbitrator must have misconceived the nature of the inquiry or arrived at an unreasonable result. A result will only be unreasonable if it is one that a reasonable arbitrator could not reach on all the material that was before the arbitrator. Material errors of fact, as well as the weight and relevance to be attached to particular facts, are not in and of themselves sufficient for an award to be set aside, but are only of any consequence if their effect is to render the outcome unreasonable.

In analysing the abovementioned summation, key jurisprudential points ${ }^{105}$ can be established. Firstly, there will be a ground for review, if a defect in the proceedings falls within one of the grounds of section 145(2)(a) of the LRA. Thus, for the defect to equate to a gross irregularity, as contemplated in section 145(2)(a), the commissioner must have misconceived the nature of the enquiry or arrived at an unreasonable result.

Secondly, a commissioner committing a material error of fact or failing to consider certain evidence, will not as such be sufficient for an award to be set aside, ${ }^{106}$ except, if it can be established that, because of the effect of such errors committed by the commissioner, ${ }^{107}$ the result of the award is rendered unreasonable.

The SCA in Herholdt therefore increased the test for prejudice in comparison to the light test set out by the LAC in Herholdt, ${ }^{108}$ and consequently narrowed the scope for interference, and in the process preserved the distinction between appeal and review.

Even though the SCA was critical about the LAC's development of the review test, it nevertheless concluded that the LAC found that the result of the award failed the Sidumo test and consequently upheld the LAC's judgment. ${ }^{109}$

\footnotetext{
Ibid.

104 Herholdt v Nedbank Ltd supra par 25.

Myburgh 201323 Contemporary Labour Law 34.

Myburgh 201323 Contemporary Labour Law 36.

Process-related review.

108 Myburgh 201323 Contemporary Labour Law 36.

109 Ibid.
} 


\section{A comparison of Herholdt and Gold Fields}

The Gold Fields judgment was the first LAC judgment to follow the abovementioned SCA judgment, in making reference to the review test. The appeal to the LAC was based on the contention that the Labour Court incorrectly dismissed ${ }^{110}$ the appellants' claim that the arbitrator committed a process-related irregularity when he miscategorised the respondent's conduct as poor performance and not that of misconduct, resulting in the arbitrator's failure to properly apply his mind to the facts. ${ }^{11}$

Taking into account that the Gold Fields's judgment directly followed the SCA judgment in Herholdt, certain key legal positions can by surmised and compared.

The SCA in Herholdt and LAC in Gold Fields dealt mainly with latent irregularities and unreasonableness, relating to factual findings made by the commissioner in establishing the guilt of the employee. ${ }^{112}$ Broader sources for reviews, such as lack of jurisdiction, errors of law and patent irregularities were not dealt with by the judgments. ${ }^{113}$

Both Herholdt and Gold Fields therefore endorsed the suffusion of the constitutional standard of reasonableness. Herholdt established that awards can be reviewed both on the listed ground in section 145 and on the ground of unreasonableness; conversely Gold Fields held that awards are only reviewable on the section 145 -listed grounds, if the additional requirement of unreasonableness is met. ${ }^{114}$

Furthermore, concerning reviews based on the failure by commissioners to consider the material facts, Herholdt and Gold Fields both found in essence that a review based on the commissioner's failure to consider the material facts, will be reviewable only if it is established that such gross irregularity caused the result of the award to be substantively unreasonable. ${ }^{115}$ In making this finding, both the judgments rejected Ngcobo J's gross-irregularity dictum and the potential-for-prejudice test set out in Herholdt (LAC), limiting the basis of review.

In addition, the LAC in Gold Fields held that, where the commissioner fails to identify the dispute to be arbitrated, he/she does not understand the nature of the dispute to be arbitrated or that the commissioner does not deal with the substantial merits of the dispute, it would, provided that the award

110 Gold Fields Mining SA (Pty) Ltd v CCMA supra par 11 - The Labour Court dismissed the review application and did so on inter alia the following bases:

(i) that although the arbitrator had miscategorised Moreki's [third respondent] conduct as poor performance instead of misconduct, this was immaterial and not unreasonable;

(ii) that while the sanction of dismissal was actually fair, the arbitrator's decision that it was unfair passed the test set in Sidumo; and

(iii) that the appellant brought predominantly a result-based review.

111 Gold Fields Mining SA (Pty) Ltd v CCMA supra par 1.

112 Myburgh 201323 Contemporary Labour Law 40.

113 Ibid.

114 Myburgh 201323 Contemporary Labour Law 40.

115 Myburgh 201323 Contemporary Labour Law 41. 
also failed the Sidumo test, qualify as additional errors within a gross irregularity. ${ }^{116}$

The most essential aspect, the operation of the Sidumo test, was addressed and confirmed by both judgments. In maintaining the distinction between an appeal and a review, both judgments emphasised that the Sidumo test will only be met if the result of the award falls outside a notional band of reasonable decision. ${ }^{117}$ This endeavour, to maintain the abovementioned division, was stressed by both Herholdt and Gold Fields, in finding that the courts should not simply focus on the errors committed by the commissioner in determining whether the Sidumo test is met, but should rather engage in a holistic analysis of all the material evidence in order to establish if the award is capable of reasonable justification. ${ }^{118}$

It could well be contended that the aforementioned jurisprudence may make it more difficult to succeed on review; nonetheless both these judgments are rooted in Sidumo, and endorsed same, resulting in a development which places us back on track, and consequently embodies the true intention of the legislature with minimal interference in the awards of the arbitrators.

\section{Conclusion}

The Sidumo test, based on the notion of reasonableness, set the platform for sound jurisprudential development, seeking to preserve the true intention of the legislature and maintain the differentiation between appeals and reviews. The interference of commissioners' awards was thus limited, encouraging the Labour Court judges not to delve into the merits of the case, but to uphold the true nature of review proceedings. Such desired development by our courts was accordingly not entertained by post Sidumo LAC judgments, as they disregarded the test set out in Sidumo, and to the contrary, formulated the basis of their judgments on the minority's view in Sidumo. Such non-reliance on the Sidumo test by the trilogy judgments ${ }^{119}$ caused the relaxation of the grounds of review and the subsequent effortless interference by Labour Court judges. This straightforward approach was based on the mere failure by the commissioner to consider the material facts that might "potentially" cause an unreasonable, substantive outcome, causing the award to be set aside and making it thus easier to succeed on review. The deviation of the Sidumo contour, however, caused the Supreme Court of Appeal to step in and correct the broad approach established by the trilogy judgments, in particular the LAC judgment of Herholdt. The SCA confirmed the suffusion of the notion of reasonableness as set out in Sidumo and relied on a more holistic approach, narrowing the scope for interference and in the process preserving the distinction between appeal and review.

In summation, concerning the current position in our law, the development of the review function of the Labour Court affords an aggrieved party an opportunity to approach the court and challenge the award of the

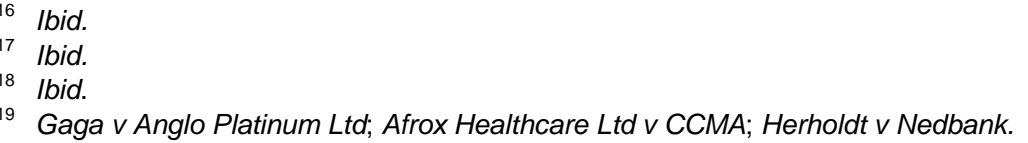


commissioner. Provided firstly, that in terms of Sidumo, the Labour Court is satisfied that the decision reached by the commissioner is not one that a reasonable decision-maker could have reached and secondly, in terms of Herholdt (SCA), that the result arrived at by the commissioner is unreasonable and in the event of errors of fact committed by such commissioner, it can only be reviewable, if the effect of such error renders the outcome to be unreasonable.

The Sidumo contour seems to have been concluded for now. However, there is no doubt that the Labour Court's review function will be developed once again in the near future. The question, however, remains, to which extent? Shall we see the Labour Courts reverting to a more relaxed approach, seeing it fit to challenge the limits of interference of arbitration awards, or will the Labour Court continue to develop this strict, controlled advance based on reasonableness?

As for now, the notion of reasonableness is thus the pivot of the review test and future development. Reasonableness ingrains a sense of structure and finality to the grounds for review and is seen as the rational factor concerning the review of arbitration awards. A comparable line can be drawn with the Sidumo contour, as reasonableness is a constant dynamic in the development of the review test. The origin of the reasonableness concept in review proceedings, is obviously found in the suffusion of the Constitutional standard of reasonableness into the section 145 grounds for review. Hence, the concept of reasonableness forms the ultimate foundation in such review proceedings.

\section{THE NOTION OF REASONABLENESS}

\section{Introduction}

The significance of the notion of reasonableness in the judicial review of arbitration awards was comprehensively accentuated in the course of this treatise. Reasonableness, without a specific legal meaning, has integrated our law as one of the standards for judicial review for administrative action, construed in section 33(1) of the Constitution. The abovementioned section provides that everyone has the right to administrative action that is lawful, reasonable and procedurally fair. The use of reasonableness therefore in such context, as confirmed by the suffusion of reasonableness into section 145 of the LRA, ${ }^{120}$ means that if the administrative action is deemed not to be reasonable, the matter is reviewable. No specific meaning can be induced to reasonableness; thus the chapter will proceed in a brief consideration of the elements of reasonableness, setting out and considering rationality and proportionality. Although the hypothesis of the subject matter is important, it is the origin and nature of the application of reasonableness that must form part of an in-depth consideration.

The encapsulation of the notion of reasonableness and subsequent application of same in our labour jurisprudence were introduced by Bato Star

120 Previous article. 
Fishing $v$ Minister of Environmental Affairs and Tourism, ${ }^{121}$ when it made reference to the so-called "Wednesbury reasonableness test". Such reference to English Law was consequently endorsed by Navsa J, in Sidumo and thus paved the way to set the platform for the confirmation that commissioners exercise administrative action, and the subsequent suffusion of section 145 with the notion of reasonableness, ${ }^{122}$ culminating in the establishment of the so-called "Sidumo test".

\section{The suffused notion of reasonableness}

According to Sidumo, the notion of reasonableness entrenched in section $33(1)$ of the Constitution is suffused into section 145 of the LRA. ${ }^{123}$ Hence, the suffused notion of reasonableness stems from "reasonable administrative action"124 and therefore as a result, equates to administrative law. It is consequently accepted in our law that in an administrative-law sense, the notion of reasonableness comprises of two elements, ${ }^{125}$ rationality and proportionality.

\section{Rationality}

Rationality is one facet of reasonableness ${ }^{126}$ and in essence it means that a decision must be supported by evidence and information before the commissioner, as well as the reason given for it. ${ }^{127} \mathrm{~A}$ decision, based on the support of the evidence and material, is thus irrational, if it is unreasoned and lacking perceived logic or clear justification. ${ }^{128}$ An example of an irrational decision is where there is an absence of a logical connection between the evidence and material before the commissioner as well as the apparent reasons for the decision. ${ }^{129}$ The abovementioned consideration was adequately surmised by the LAC judgment in Carephone: ${ }^{130}$

"Is there a rational objective basis justifying the conclusion made by the administrative decision-maker between the material properly available to him and the conclusion he or she eventually arrived at?"

The summation was therefore applied and approved by the SCA in Trinity Broadcasting $v$ Independent Communications Authority of South Africa, ${ }^{132}$ which consequently recognised rationality ${ }^{133}$ as a ground for review. ${ }^{134}$

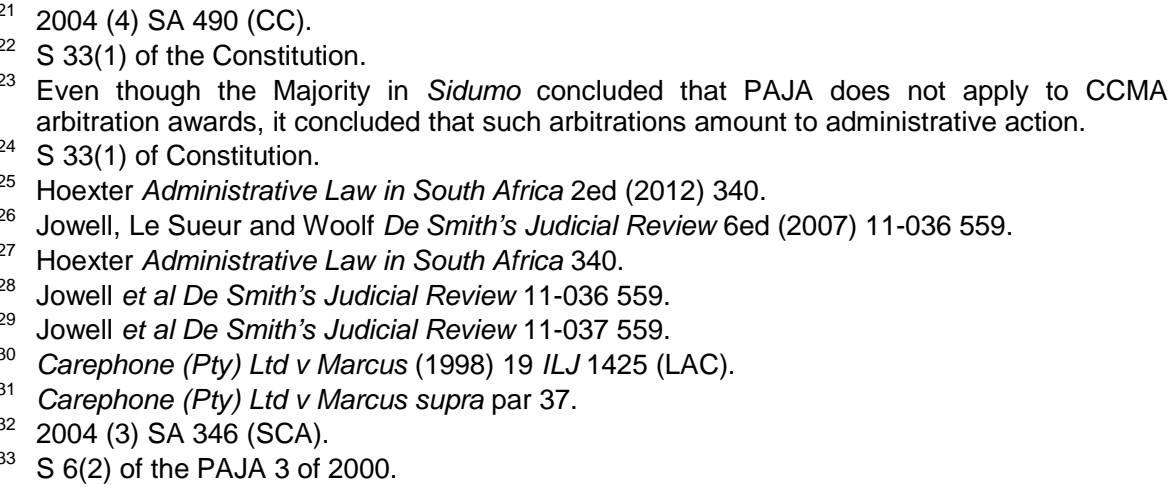


However, in Sidumo, the Constitutional Court was more concerned with the constitutional standard of reasonableness, encapsulated in section 33(1) of the Constitution, than the specific grounds of review in the PAJA. ${ }^{135}$ Therefore, the fact that Sidumo focused particularly on reasonableness only and being silent as to rationality, is indicative that the two grounds might come to the same thing. ${ }^{136}$ However, according to Hoexter: "they should certainly continue to be regarded as separate and more or less independent grounds of review - not only because the PAJA lists them as separately but also because reasonableness goes beyond mere rationality" ${ }^{\prime 137}$ (author's own emphasis).

As established, the terms rationality and reasonableness are often used interchangeably, however, rationality is only one facet of reasonableness and not all there is to reasonableness. ${ }^{138}$

\section{Proportionality}

The notion of proportionality requires the decision-maker to achieve a fair balance ${ }^{139}$ and thus "to avoid the imbalance between the adverse and beneficial effects of an action, and to encourage the administrator to consider both the need for the action and the possible use of less drastic or oppressive means to accomplish the desired end". ${ }^{140}$ The fundamentals that are thus drawn from the notion ${ }^{141}$ are the balance of relevant considerations $^{142}$ and the appropriateness or acceptability ${ }^{143}$ of the decision. The notion may be basically defined as "to use a sledgehammer to crack a nut". ${ }^{144}$

Even though the notion of proportionality derives from German law, ${ }^{145}$ it is very similar to the so-called "Wednesbury reasonableness test", where Lord Greene, M.R. stated that the courts can interfere only if a decision:

"is so unreasonable that no reasonable authority could ever come to it". ${ }^{46}$

Hoexter Administrative Law in South Africa 341

Supra ft 5.

Hoexter Administrative Law in South Africa 343.

Ibid.

Jowell et al De Smith`s Judicial Review 11-036 559.

Jowell et al De Smith's Judicial Review 11-075 585.

140 Hoexter Administrative Law in South Africa 344.

141 Ibid.

142 Jowell et al De Smith's Judicial Review 11-075 585 - "the courts evaluate whether manifestly disproportionate weight has been attached to one or other considerations relevant to the decision".

143 Jowell et al De Smith's Judicial Review 11-075 585 - "the courts consider whether there has been a disproportionate interference with the claimant's rights or interests. There will of course always be an examination of rationality in its narrow sense of logical connection between ends and means".

144 Hoexter Administrative Law in South Africa 344

145 Ibid.

146 Associated Provincial Picture Houses Limited v Wednesbury Corporation [1948] 1 KB 223 229-230. 
Although vague and confusing, this formulation endeavours to point out that judges should not lightly interfere with the decisions of officials. ${ }^{147}$ In exercising their powers of review, the judges ought not to place themselves in the position of the competent authority and test such decision in accordance with their own sense of reasonableness. In doing this, the court will engage in considering the merits of the decision. ${ }^{148}$ Therefore, according to Lord Greene in Wednesbury, unreasonableness under his definition would require something overwhelming. ${ }^{149}$

There have subsequently been various attempts to reformulate the Wednesbury test, however, such reformulation amounts to no more than a helpful guide to the parameters. ${ }^{150}$ Lord Cooke, in $R v$ Chief Constable of Sussex, ${ }^{151}$ regretted the fact that the Wednesbury formula had been established in the UK courts and beyond. ${ }^{152}$ Lord Cooke subsequently relied upon a more simple test of:

"whether the decision in question was one which a reasonable authority could reach."

It is the abovementioned view and dictum that were cited in Bato Star Fishing, confirming the confusing nature of the Wednesbury test and that the approach of Lord Cooke provides proper sound guidance:

"In determining the proper meaning of section 6(2)(h) of PAJA in the light of the overall constitutional obligation upon administrative decision-makers to act reasonably."

"Section 6(2)(h) should then be understood to require a simple test, namely, that an administrative decision will be reviewable if, in Lord Cooke's words, it is one that a reasonable decision-maker could not reach."

This approach was accordingly endorsed by the Honourable Acting Judge Navsa in Sidumo:

"The reasonableness standard was dealt with in Bato Star. In the context of section 6(2)(h) of PAJA, O'Regan J said the following: "[A]n administrative decision will be reviewable if, in Lord Cooke's words, it is one that a reasonable decision-maker could not reach."

This subsequently paved the way to set the platform for the confirmation that commissioners exercise administrative action with subsequent suffusion of section 145 of the LRA with the concept of reasonableness, ${ }^{157}$ and the resulting establishment of the so-called "Sidumo test". With the application of the Wednesbury standard preferred by the UK courts, reasonableness is a

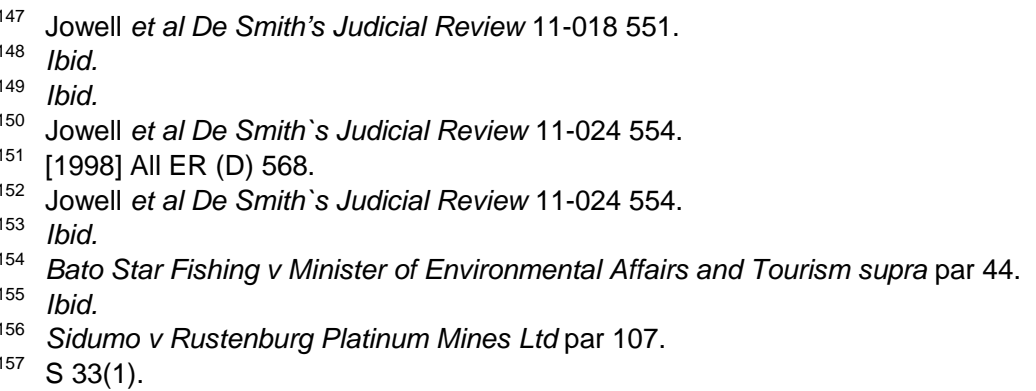


more stringent test, based on a standard requiring perversity, ${ }^{158}$ irrationality or extreme unreasonableness, in comparison to such application in South Africa. The extent of the application of the notion of reasonableness in South Africa, compared to the application in the UK, should thus be considered and analysed.

\section{The comparative element of reasonableness within the United Kingdom's legal system}

With the reliance on Lord Cooke's dictum, Sidumo ultimately reached the conclusion that the requirement of reasonableness for just administrative action must be suffused into section 145. Accordingly our labour jurisprudence was influenced by English administrative law. ${ }^{159}$ It therefore warrants assessing whether the notion of reasonableness is applied similarly to that of Employment Law in the UK, and consequently, the comparative nature of the application of reasonableness between South Africa and the UK. An apparent and logical commencement of such comparison is the practical application of the notion of reasonableness and, in particular, the respective judicial medium that initiates such application.

Employment-dispute resolution in the UK comprises of a twofold system, based on the Advisory, Conciliation and Arbitration Service (ACAS) Arbitration Scheme, ${ }^{160}$ which provides that aggrieved parties to unfair dismissal disputes, may after conciliation, agree in writing to refer their dispute to arbitration by an arbitrator appointed by ACAS, as an alternative to the Employment Tribunal (ET) hearings. ${ }^{161}$ The alternative arbitration introduced by ACAS, adopts an inquisitorial approach, ${ }^{162}$ providing for a more informal, speedier, more private and less costly alternative ${ }^{163}$ to an Employment Tribunal case. Legal representation is not necessary and strict adherence to legal principles and legal precedents will not be entertained, even though the arbitrator makes an award which is binding on the parties. ${ }^{164}$ It could thus be said that the arbitration proceedings in accordance with ACAS is a great deal similar to that of the CCMA. However, contrary to that of the ET's, ${ }^{165}$ there is an exclusion of an appeal procedure, which provides that the parties may appeal only in instances of a serious irregularity. Therefore, for the purpose of analysing and comparing the practical application of Reasonableness, the judicial medium of Employment Tribunal's takes preference.

\footnotetext{
Selwyn Selwyn's Law of Employment 13ed (2004) 20.139499.

Associated Provincial Picture Houses Limited $v$ Wednesbury Corporation supra.

Hardy Labour Law and Industrial Relations in Great Britain 3ed (2007) 9270.

1 Hardy Labour Law and Industrial Relations in Great Britain 8062.

162 Selwyn Selwyn's Law of Employment 1.135.

63 Hardy Labour Law and Industrial Relations in Great Britain 8062.

${ }^{64}$ Selwyn Selwyn's Law of Employment 1.135.

165 Hardy Labour Law and Industrial Relations in Great Britain 9672.
} 


\section{Employment Tribunals and the CCMA}

In order to assess the intended comparison and attaining the ultimate conclusion, the jurisdiction, procedure, composition as well as the appeal and review procedure of the ET are considered and compared to those of the CCMA. Such comparison, in particular the evaluation of the composition and appeal and review procedure, identifies the dilemma in the application of review proceedings in our labour jurisprudence.

\section{311 Employment tribunals}

ETs form part of a specialised system of inferior labour courts in the UK, ${ }^{166}$ with its jurisdiction expanded to cover almost all the statutory individual rights, for instance, complaints of unfair dismissal, redundancy payment, failure to consult over proposed redundancies, equal pay, breach of employment provisions of legislation, unjustifiable discipline, etcetera. ${ }^{167}$ The procedure governing the ETs is the Employment Tribunals' regulations $2013^{168}$ and, in contrast to the CCMA, the adversarial system prevails, shifting the responsibility on each party to present and prove its own case, with no investigating power by the commissioner and no power to promote or order a compromise between the parties. ${ }^{169}$ The nature of the system consequently creates the need for legal representation, unlike the CCMA, where such legal representation is not common. ${ }^{170}$

Conversely, the Employment Tribunals, like the CCMA, act much more speedily than ordinary courts and, with national jurisdiction, are more accessible to complainants. ${ }^{171}$ Even though ETs are subject to the adversarial system, they are more informal, with no complicated pleadings and not bound by normal rules of evidence. ${ }^{1 / 2}$

A significant and interesting distinction between Employment Tribunals and the CCMA, is its tripartite composition. ${ }^{173}$ The ETs consist of a legal chairman and two lay members. The legal chairman is required to have at least seven years' experience as a solicitor or barrister and is drawn from a panel of chairmen appointed by the Lord Chancellor. ${ }^{174}$ The two lay members, one with employment and the other with industrial experience, ${ }^{1 / 5}$ are selected on a part-time basis from a panel drawn up after consultations with employers' organisations and trade unions. ${ }^{176}$ In South Africa, however, irrespective of whether there is only one presiding commissioner, the

\footnotetext{
Selwyn Selwyn's Law of Employment 1.419.

Hardy Labour Law and Industrial Relations in Great Britain 9068.

168 The Employment Tribunals (Constitution and Rules of Procedure) Regulations 2013 No 1237.

169 Hardy Labour Law and Industrial Relations in Great Britain 9370.

170 Hardy Labour Law and Industrial Relations in Great Britain 9471.

171 Hardy Labour Law and Industrial Relations in Great Britain 9370.

172 lbid.

173 Hardy Labour Law and Industrial Relations in Great Britain 9269.

174 Selwyn Selwyn's Law of Employment 1.429.

175 Hardy Labour Law and Industrial Relations in Great Britain 9269.

176 Selwyn Selwyn's Law of Employment 1.429.
} 
governing body of the CCMA may simply appoint an adequately qualified person ${ }^{177}$ as a commissioner, and no need for legal qualifications is required. The presumption may thus be made that Employment Tribunals, with their tripartite-legal-experience background, are superior to and more capable in assessing the merits of a matter than the commissioners of the CCMA. Consequently in contrast to the CCMA, such superior judgments are of a better quality, ${ }^{178}$ resulting in a different nature and application of review and appeal proceedings.

Arguably, the core-functioning of ETs and the CCMA is different, in particular its composition. Hence, the comparison between the two legal systems consequently identifies a key consequence of the CCMA's composition, namely the interference of the commissioners' awards by our courts. The basis of such identification is reliant on the comparison between the appeal and review proceedings of the two systems, which ultimately depends on the notion of reasonableness.

Even though our labour legislation and jurisprudence are suffused with the notion of reasonableness derived from administrative law, and consequently influenced by Lord Cooke's dictum set out in Bato Star and confirmed in Sidumo, ${ }^{179}$ the subsequent consideration is in respect of the UK's inferior courts and not administrative tribunals.

\section{Review and appeal procedures}

In the UK, an application for review may be made only on the ground that there has been an error in the proceedings, and may not be based on the contention that the employment tribunal has committed an error in law. ${ }^{180}$ Such contention must be entertained through an appeal process to the Employment Appeal Tribunal (EAT).

In order to succeed in such an application to the EAT, it must be established that the ET "misdirected themselves in law, or entertained the wrong issue, or proceeded on a misapprehension or misconstruction of the evidence, or taken matters into account which were irrelevant to the decision, or reached a decision which no reasonable employment tribunal, properly directing themselves in law, could have arrived at"."

The first four of the aforementioned grounds are very similar to Ngcobo's gross irregularity dictum, ${ }^{183}$ where the commissioner commits a latent irregularity, ${ }_{184}$ occurring in the mind of the commissioner at the time of writing the award, and where it appears that the material facts were ignored, causing the commissioner to misconceive the whole nature of the enquiry. ${ }^{185}$ The latter, based on reasonableness, is identical to the notion encapsulated

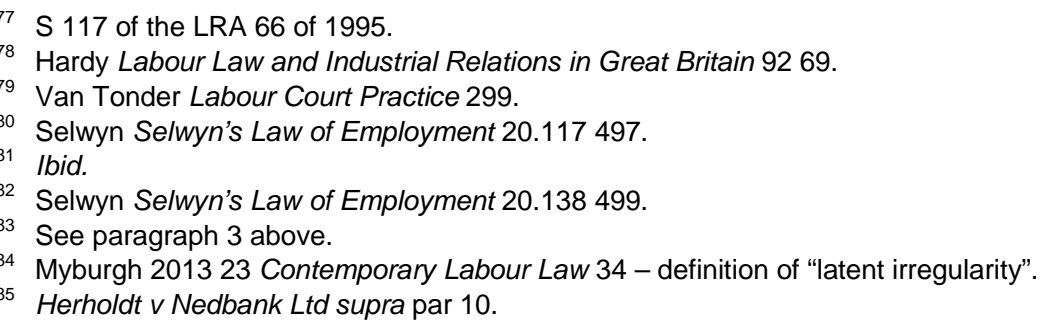


in Sidumo and subsequent suffusion into section 145. Debatably, with reference to section 145 of the LRA, our review proceedings are a combination of the UK's appeal and review actions.

The issue, however, is the application of the notion of reasonableness and the measure of interference by the courts. In the UK, the EAT would not normally interfere with decisions of the ETs, unless if it is possible to say, according to Lord Justice May: ${ }^{866}$ "My word, that was certainly wrong!" there are reasonable grounds to support the decision, the EAT would not interfere and will thus do same only if there has been a measure of extreme unreasonableness. ${ }^{18}$ In East Berkshire Health Authority $v$ Matadeen ${ }^{189}$ the EAT held that "perversity" is a ground for interference with an employment tribunal's decision, in the event where such decision "was not a permissible option" or was "a conclusion that offends reason" or "so outrages in its defiance of logic or of acceptable standards of industrial relations". ${ }^{190}$ The principle of non-interference is based on the premise that the lay members of the tribunal ought to exercise their experience and industrial judgment concerning questions of law and decisions to be reached. ${ }^{191}$ Accordingly, the consideration and weight to be attached to the evidence remain the sole task of the ET and it is thus not permissible for the EAT to replace the outcome of the decision with its own views. ${ }^{192}$

Contrary to the approach in the UK, the South African Labour Courts tend to exploit the reasonable decision-maker and rationality test, by endorsing a more relaxed approach to the application of reasonableness and gross irregularity. ${ }^{193}$ Hence, in assessing whether the decision was not one that a reasonable decision-maker could have arrived at, the door is opened for the Labour Court to interfere and consequently permit "merit reviews". ${ }^{194}$ In practice some of our Labour Court judges are prepared to go further than others when it comes to the reviewing of the merits, even though it is contended that they are upholding the distinction between appeal and review and are not concerned with the correctness of the decision. ${ }^{195}$ Even with the recent re-establishment and development of the Sidumo test and consequent stringent test to be applied by our Labour Courts ${ }^{196}$ in review proceedings, it will not necessarily prevent such interference in its totality. The problem is consequently to establish the cause of such interference and the prevention thereof subsequently.

Guidance is sought by the mode of the approach and composition of the United Kingdom's ETs. The reality of the matter is that the EAT seldom interferes with the decisions of the ETs and if so, only in cases of extreme unreasonableness. The premise of such limited interference is fairly obvious:

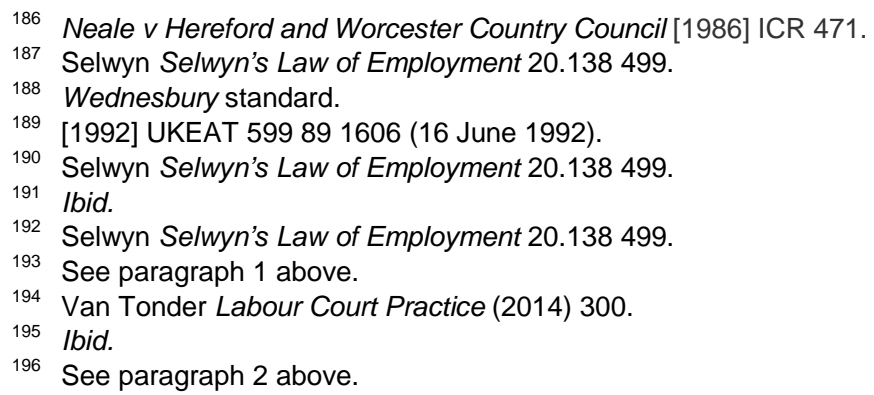


the reason lies in the composition of the ETs, and as a result of such composition: the strict test applied by the EAT for unreasonableness.

To put it in perspective, the EAT will not necessarily interfere with a decision of an ET, while being well aware that the basis of such decision was formulated and made by a legal chairman with seven years' legal experience as a solicitor and two lay members with extensive experience in industry and employment respectively. The lay members, acting as neutral arbiters, rely on their experience in industrial relations to enhance the quality of the decision. ${ }^{197}$ The tripartite structure provides for one equal vote by each member, and taking into account the diverse background of the members, $96 \%$ of all decisions reached are unanimous, including decisions where the legal chairman does not have the support of one of the "wingmen" and are thus outvoted by the two lay members.

Therefore, in comparing such advanced composition with that of the CCMA, it is apparent that the requirements for the appointment of CCMA commissioners are less stringent. Section 117 of the LRA merely provides that:

"(1) The governing body must appoint as Commissioners as many adequately qualified persons as it considers necessary to perform the functions of commissioners by or in terms of this Act or any other law."

According to the CCMA, ${ }^{199}$ the Commissioners are appointed by the Governing Body of the CCMA on the strength of their experience and expertise in labour matters, particularly dispute prevention and dispute resolution. In addition, the CCMA Commissioner Appointment and Recruitment Process ${ }^{200}$ sets out minimum requirements for appointment of an entry level - level B Commissioner. It provides that such aspirant applicant must have at least four years' experience in industrial relations, labour law or conducting conciliations, arbitrations and facilitations, supported by relevant tertiary qualifications or NQF 5 equivalent, preferably in labour law, good knowledge of labour law, good knowledge of conciliation, arbitration and mediation processes and principles, good knowledge of the labour market and the different relevant factors. ${ }^{20}$

In some instances, such "adequately qualified" commissioners possess a measure of experience and expertise that is more advanced than most legal practitioners, and the assertion made is not done without the necessary respect towards the majority of the CCMA commissioners. However, the interference by the Labour Court judges is based on the disproportionate gap in legal knowledge, legal experience, legal qualifications, legal skill and interpretation of our labour jurisprudence and labour legislation. Before

Hardy Labour Law and Industrial Relations in Great Britain 9269.

198 Selwyn Selwyn's Law of Employment 1.429.

199 CCMA "Commissioners" (2014) http://www.ccma.org.za/Display.asp?L1=31\&L2=4 (accessed 2014-11-14).

200 CCMA "How to become a CCMA Commissioner" (2014) http://www.ccma.org.za/Display. asp?L1=54. (accessed 2014-11-14) 2.

201 CCMA http://www.ccma.org.za/Display.asp?L1=54. 2 - Other requirements includes a valid Driver's Licence; Computer literacy; Analysis, Problem-solving, Judgment; Decision-making, Resilience, Listening, Communication; Negotiating and Influencing; Diversity awareness, Conflict management; Diplomacy; Interpersonal Relations; and Sound Ethics. 
stepping up to the bench, the majority of these Labour Court judges, practised for decades as advocates and attorneys and thus litigated on a daily basis. Measured by the minimum requirements for the appointment as a commissioner, the disproportionate gap in legal knowledge, experience and qualifications is evident. It may thus as a result of such imbalance, which warrants the perception by some Labour Court judges, that the majority of the CCMA commissioners are lacking the required ability to assess the legal issues and apply their minds to the merits and judgment of the case, and so come to the conclusion that the decision reached by a commissioner is not one that a reasonable decision-maker could have reached on the evidential material available. ${ }^{202}$

\section{Conclusion}

The notion of reasonableness is the decisive test applied by our labour courts in review proceedings and is confined within the restored and redeveloped Sidumo test. The origin of reasonableness in the review of employment matters, is based on an administrative-law influence ${ }^{203}$ and the Wednesbury test, conveyed into our labour jurisprudence by Bato Star Fishing and expanded upon by Sidumo. As established and confirmed by the preceding chapters, the notion of reasonableness is surmised within the test applied to establish whether the decision reached by the commissioner is one that a reasonable decision-maker could not have reached with the evidential material available.

The need for the restitution and subsequent development of the abovementioned test, is based on the assertion that a more relaxed test simplifies the interference by Labour Court judges with the awards of the commissioners, and thus breaches the common line between appeals and reviews. Such merit reviews are in conflict with the true intention of the legislature. The attempt to narrow the scope of interference is found in the Sidumo test. However, even though the test is characterized by stricter grounds than in the past, ${ }^{204}$ the test remains a double-edged sword, hinging upon the notion of reasonableness.

Even though reasonableness must now be added as one of the section 145 grounds in order to set aside the award, the notion nevertheless also creates an opportunity for Labour Court judges to partake in the consideration of the merits of the award. Applying a lighter test for unreasonableness, in comparison with the more stringent test for gross unreasonableness in the UK, prompts the Labour Court judges to without doubting consider the merits of the case. With a greater tolerance for unreasonableness, the majority of Labour Court judges assess whether the decision reached by the commissioner is one that a reasonable decisionmaker could not have reached, and consequently find that the decision has been in fact in accordance with the thinking of a reasonable decision-maker.

202 Van Tonder Labour Court Practice 300.

203 S 33(1) of the Constitution.

204 See paragraph 2 above. 
The derivation of such finding by the Labour Court is, however, the interference with the award itself. Such interference originates in the subjective consideration of the Labour Court judge, that the commissioner's capability to adjudge the merits and apply the law accordingly, is not adequate. Such subjective contemplation is based on the gap between Labour Court judges and commissioners. Our Labour Court judges, unlike the EAT in the UK, breach the fine line between appeal and review to assess whether the commissioner has made the correct decision, and consequently alter the result if it "is not one that a reasonable decision-maker could have made".

In order to prevent such mistrust in the legal abilities of our commissioners, it is my respectful view that the CCMA need to re-evaluate the recruitment, training and appointment of commissioners. It is agreed that a carbon copy of the United Kingdom's Employment Tribunals' composition would not be financially viable within the budget constraints of the CCMA and therefore interfere with our expeditious resolution regarding the dispute structure, as there are not sufficient resources to establish a tripartite commission, nor to appoint senior attorneys or advocates on a comprehensive basis. However, subject to non-discrimination, the CCMA may be able to give preference to legal practitioners with relevant qualifications and experience, followed by a process where non-legal practitioners are appointed on the premise that they at least have a tertiary qualification in labour law and eight years' experience in an industrialrelations capacity. Such a proposal to attain formal qualifications is not unfounded. In 2013, the CCMA ${ }^{205}$ embarked on an initiative to partner with Public Universities ${ }^{206}$ "to develop and deliver a qualification in LabourResolution Practice", which will in due course replace the current CCMA candidate-training programme. ${ }^{207}$ The qualification will be at a post-graduate level, equivalent to a NQF level 8 and intend to "prepare graduates who are ready for practice, both skilled and well-rounded practitioners". The qualification will include "all core aspects of the current CCMA commissioner training; training in substantive law and in-depth technical skills training on arbitration and conciliation; components on soft-skills, social justice, ethics, diversity and other topics". ${ }^{208}$ The programme commenced in 2014.

Consequently, such qualification and proposed increased level of a number of years' required experience, together with the suggested preference to legal practitioners, attempt to the narrow the gap between the Labour Court judges and CCMA commissioners. Ultimately, Labour Court judges will always have superior understanding and application of the law. However, the perception that our CCMA commissioners are not able to reach a decision that a reasonable decision-maker could have reached, could be avoided by instilling a sense confidence in our commissioners,

205 CCMA "A New Labour Dispute Resolution Practice Qualification to be launched" (15 October 2013) http://www.ccma.org.za/ViewNews.asp?NID=205 (accessed 2014-11-14).

206 The University of the Western Cape, the Nelson Mandela Metropolitan University, the University of the Witwatersrand, the University of the Free State and Stellenbosch University.

207 CCMA http://www.ccma.org.za/ViewNews.asp?NID=205.

208 Ibid. 
based on the increased level of knowledge and skill within the broad labourrelations arena in South Africa.

\section{$4 \quad$ CONCLUSION}

In considering and analysing the contour of Sidumo, the principal objective of this treatise was to identify the correct test to be applied in review proceedings stemming from the CCMA. The consideration and analyses of the development of the review test were based on various judgments seeking to expand upon such test. Sidumo, was obviously the primary consideration, forming the basis and departure of the contour, followed by a trilogy of contentious Labour Appeal Court judgments, deluding the contour with an inexact development, resulting in a wider application of the review test. Such deviation from Sidumo impelled the Supreme Court of Appeal and an ensuing judgment in the Labour Court to rectify such misapplication, by reaffirming the application of the Sidumo test and supporting a narrower and stringent approach, thus maintaining the strict distinction between appeal and review. A further objective, deriving from the principal purpose of this treatise, was to consider the proverbial distinction between appeal and review and the consequent extent of the distortion of such distinction, caused by the interference of our Labour Court judges in the awards of the commissioners. The treatise's objectives were integrated by a constant and continuous thread of reasonableness, forming the basis for the Sidumo test and application of the interference by our Labour Court judges.

The Sidumo contour was based on the standard of review, set out by the majority in the Sidumo judgment and supported by the notion of reasonableness. It was confirmed that a reviewing court must ensure that a commissioner's decision falls within the bounds of reasonableness. The court delegated with such determination, should enquire whether such is one that a reasonable decision-maker could not have reached. Such consideration formed the basis for the Sidumo contour. The Sidumo tests set the platform for sound jurisprudential development, seeking to preserve the true intention of the legislature and to maintain the differentiation between appeals and reviews.

An additional consideration and assessment had to be made of the three controversial judgments. Gaga, Afrox Healthcare and Herholdt sought to clarify the approach adopted by Sidumo, and endorsed a wider application to review proceedings, confirming that CCMA awards can be reviewed on section 145 grounds and on the basis of unreasonableness. Moreover, the approach was more simplified in Herholdt, in finding that a mere failure by a commissioner to consider the material facts that might potentially cause an unreasonable substantive outcome, causes the award to be set aside. Such non-reliance on the Sidumo test has caused the relaxation of the grounds of review and the subsequent ardent interference by Labour Court judges. Such divergence from the Sidumo contour was averted by the Supreme Court of Appeal judgment on Herholdt and subsequent Labour Appeal Court judgment in Gold Fields. In particular, the SCA judgment of Herholdt contained the decisive response emphasized in the objective of the treatise. The SCA confirmed the suffusion of the notion of reasonableness as set out in Sidumo and relied on a more holistic approach, narrowing the scope for 
interference by Labour Court judges, preserving the distinction between appeal and review and in the process, culminating the Sidumo contour.

The primary finding of this treatise concerns the current position in our law relating to the test for review. The premise of such review test to applied by our Labour Courts, affords an aggrieved party to approach the court and challenge the award of the commissioner. Such challenge would be only entertained if the Labour Court is satisfied that the decision reached by the commissioner, is not one that a reasonable decision-maker could have reached in the court, and that the result arrived at by the commissioner is unreasonable.

In considering the distinction between appeal and review and the subsequent extent of the distortion of such distinction, the true intention of the legislature was emphasised and analysed. However, it was the comparative study made with the relevant law of the United Kingdom that identified the defect in the application of our review proceedings, in creating a backdoor for our Labour Court judges to consider the merits or not of a specific case.

In comparing our labour jurisprudence with that of the United Kingdom, it was found that the test of unreasonableness applied by our courts, is clearly lighter than the stringent test for gross unreasonableness applied in the United Kingdom. In addition, it was found that the composition of the United Kingdom's Employment Tribunal is to a larger extent based on legal experience and legal qualifications than the composition of the CCMA.

The resulting secondary finding of the treatise underlines the light test of unreasonableness applied by our courts and the measure of distrust in the ability of our commissioners, consequently confirming the backdoor for our labour court judges, enabling them to consider the merits of the dispute without difficulty and finding that the decision reached by the commissioner is one that a reasonable decision-maker could not have reached. The extent of interference into the merits is thus established and accentuated against the strict backdrop of the United Kingdom's limited interference.

Even though the Sidumo contour concluded with the contemporary SCA and LAC judgments, there is the capacity for a great deal of further development in our labour-law jurisprudence and labour-law judicial system, in particular the review test. In order to abide by the legislature's true intention and maintain the distinction between appeal and review, the required development of such review test should entail a stricter and narrower approach, based on gross unreasonableness, as reflected in the comparative study. The judicial structure is currently also in a phase of development and will as well require a narrowed approach to commissioner recruitment. All things considered, our labour-law jurisprudence and judicial system should constantly evolve to fit our constitutional needs and social order as well as employment demands, which will ultimately be dictated by our courts' interpretation of lawfulness, reasonableness and fairness. 